\title{
Harmonization and Comparison with EU Law of Corporate Governance in Albania
}

\author{
Aurora Ndreu (MA) (LL.M) (PhD cand)
}

Master Programme "South East European Law and European Integration" (LL.M), Karl-Franzens Universitaet Email:n.aurora@yahoo.com

\author{
Doi:10.5901/mjss.2015.v6n4s3p233
}

\begin{abstract}
One must recognize that each country has its own corporate culture, national personality and priorities, so there is no single agreed system of "good" governance. The purpose of this study is to further understand the commonalities and differences of corporate governance practices in Albania and EU countries through an analysis of corporate governance codes, practices and legal framework. This research tends to interpret and give information about Albanian company law in the light of provisions of EU company law, which it transposes, focused on corporate governance. The comparison includes legal treaties, dissertations, articles and books, papers on corporate governance. Also there was a consultation with Regulatory Authorities of corporate governance in Albania. Albania has decided to harmonize the national law with that of European law, but Albanian legislator mostly has deviated in their provisions from EU Law. One could realize that this came from the incapability of Albanian market to absorb EU provisions, or from the incapability of Albanian politicians walk in the right path of EU because of the fact this could jeopardize their economic interests. As a result it is urgently needed the expertise of qualified lawyers, not only to understand better the new trends on corporate law but to implement the law properly.
\end{abstract}

Keywords: Corporate governance, Albanian Company Law, European Union Law, comparison, harmonisation.

\section{What is Corporate Governance?}

Despite all the research and studies, there is no single definition of corporate governance that can be applied to all situations and jurisdictions. The various definitions that exist today largely depend on the institution or the author, country and legal tradition. International Finance Corporation defines corporate governance as "the structures and processes for the direction and control of companies"(International Finance Corporation, 2010, Corporate Governance Manual Second Edition). On the other part, The Organization for Economic Cooperation and Development (OECD), which in 1999 published its Principles of Corporate Governance 2000, offers a more detailed definition of corporate governance as a system of relationships, defined by structures and processes. For example, the relationship between shareholders and management consists of the former providing capital to the latter to achieve a return on their investment. On the other hand, managers are to provide shareholders with financial and operational reports on a regular basis and of course in a transparent manner. "Corporate governance also provides the structure through which the objectives of the company are set, and the means of attaining those objectives and monitoring performance are determined. Good corporate governance should provide proper incentives for the board and management to pursue objectives that are in the interests of the company and shareholders, and should facilitate effective monitoring, thereby encouraging firms to use resources more efficiently."(OECD Principles of Corporate Governance). Generally it involves the mechanisms by which a business enterprise, is directed and controlled. It usually concerns mechanisms by which corporate managers are held accountable for corporate conduct and performance (Comparative study of corporate governance codes relevant to EU and its Member States (on behalf of the European Commission) Internal Market Directorate General, Final report and Annexes- January 2002 (Corporate governance codes, 'pt' 1, 6) Although corporate governance is distinct from and should not be confused with the topics of business management and corporate responsibility, they are related.

"Corporate governance...involves a set of relationships between a company's management, its board, its shareholders and other stakeholders. Corporate governance also provides the structure through which the objectives of the company are set, and the means of attaining those objectives and monitoring performance are determined."(OECD Principles, Preamble)

Corporate governance is also "the system by which companies are directed and controlled"(IFC, Corporate Governance Manual( second edition) 6). It involves regulatory and market mechanisms, and the roles and relationships between a company's management, its board, its shareholders and other stakeholders, and the goals for which the corporation is governed. 
Also, is the set of processes, customs, policies, laws and institutions affecting the way a corporation is directed, administered or controlled. In contemporary business corporations, the main external stakeholder groups are shareholders, debtholders, trade creditors, suppliers, customers and communities affected by the corporation's activities. Internal stakeholders are the board of directors, executives, and other employees.

Corporate governance defines the legal and factual framework, internal (corporate bodies) and external framework (stakeholders) of the company.

Among other corporate governance definitions we find: "Corporate governance is the organisation of the administration and management of companies..."( Recommendations of the Federation of Belgian companies, Foreword, European Commission, Internal Market Directorate General, Comparative study of corporate governance codes relevant to the EU and its members ( final report and annexes 1-3) [January 2002] 30) or "Corporate governance is used to describe the system of rules and procedures employed in the conduct and control of listed companies"( Commission Recommendations (EC) Introduction, Portugal, European Commission, Internal Market Directorate General, Comparative study of corporate governance codes relevant to the EU and its members (final report and annexes 1-3) [ January 2002] 30).

\section{The History of Corporate Governance in Albania. Legal Framework}

Corporate governance framework reflected and included in company law, typically comprises elements of legislation, regulation, self-regulatory arrangements, voluntary commitments and business practices that are the result of country specific circumstances, history and tradition. When new experience accrues and business circumstances change, the content and structure of this framework needs to be adjusted (OECD Principles of Corporate Governance, Annotations to the OECD Principles of Corporate Governance, ensuring an effective corporate governance framework. See also www.oecd.org). So the companies would need to regularly and carefully monitor such adjustments and update their governance system.

The really first step on Company Law and corporate governance in Albania was made in 1929, by Civil Code (Available at<http://albarchive.gov.al/cms/front_content.php?idcat=192> 'accessed 11 October 2012') enacted on April 1, 1929. This Code was developed under the influence of Civil Code of France. At the other hand, even the German, Italian and Swiss law have inspired Albanian legislator on drafting Zog Civil Code. Entry into force of this code has imposed the belonging of Albanian Civil Law to the Roman-Germanic family, detaching it from the Ottoman origin.

The second step on these developments was made in 1981, during the dictatorial period. enacted by Law no. 6340 from 26.06.1981, and was inspired by socialist doctrine of East European Block, but also had a German pattern.

Albanian Company Law (Bachner T., Schuster E-PH. \& Winner M.(2009), The new Albanian Company Law (Center of Legal Competence, corp. ed. Guttenberg, Tirana) 15), under which the corporate governance, has changed many times since the early 90', when dictatorial period fell and market economy entered in force. The first step on market economy period, started by Law no. 7638 dating 19.11.1992 "Law on Commercial Enterprises". In 1995 we had another law "Transformation of State entities into private enterprises" by which all state enterprises have to become private. Later on were made many changes to the first law, that of 1992. This was made in 1995, 1996 and 2007.

A new law on commercial register and commercial companies has been enacted in 2007 and 2008. The changes have not been only technical but in all its entirety as company law framework in Albania. According to Albanian corporate governance legislation, there was a well-known and stable tradition of the two-tier system, where there was a complete division of board of administration and supervisory board functions. As we will notice further on, there are other commercial laws in Albanian legislation that were not updated with the new terminology of the new law no. 9901 "On entrepreneurs and companies", where it is still used the term "director" instead of "administrator".

Many of the changes in company law/corporate governance were done through harmonization and approximation to European Union standards.

In connection with the legal framework of corporate governance in Albania one must mention also:

- "Law on securities"( Available at:< http://tse.com.al/?fq=Brenda\&gj2\&kid=30 > 'accessed 7 November 2012'), this law determines types of securities, regulate the manner of and conditions for issuing, trading and registration, identification, and performance of transactions in securities and persons and individuals authorized to perform transactions with securities, the conditions for the organization of the public trading of securities, the protection of investors and the securities-right holders, and the conditions for dematerialized securities, exchanging and regulation of the securities market.

- Statute of Tirana Stock Exchange,

- Code of Ethics of Tirana Stock Exchange, this is a statement of values and principles that should guide the 
work of managing staff and all other employees. The Code of Ethics is an integral part of the contract of employment that should apply to all employees of the TSE. Staff members will apply the highest standards of personal ethics in the performance of functional tasks entrusted and maintaining accountability. High standards of personal ethics should include a strong personal commitment from every member of staff to act with honesty, integrity and unquestionable impartiality and respect for each individual in all relationships with colleagues and the general public. The Code of Ethics was approved by the meeting of the Supervisory Council of the TSE.

\section{Administration of Join-stock Companies}

The Joint-Stock Companies contrary to Limited Liability Companies, offers a better and suitable organizational framework for companies that runs large businesses and have a large number of shareholders. The main characteristic of JSC is the possibility to offer its shares to the public (in contrary to this characteristic the LLC cannot offer them to the public).

Generally, the Joint-Stock company has the following characteristics (International Finance Corporation, 2010, Corporate Governance Manual, 41):

- limited liability

- independent legal status and can enter into contracts in its own name

- equity capital, referred as "charter capital", divided into shares which are freely transferable

- may issue shares and bonds.

Joint-stock companies are the only legal entities that can issue shares. These shares (International Finance Corporation, 2010, Corporate Governance Manual, 41) may be: ordinary shares or preferred shares (such as voting preference shares, redeemable preference shares, dividend preference shares and other preference shares as determined in the charter of the company). The shareholders of a joint-stock company are normally liable for the debts and other property obligations of the company up to the amount of capital they have contributed to the company.(Eisenberg M.A., The structure of Corporation Law (Columbia Law Review, (1989) 1461 Until all subscribed founding shares are fully paid up, all founding shareholders are jointly responsible for the debts and other property obligations of the company up to the value of shares not yet paid for.

According to the Albanian Law, joint stock companies are commercial companies, with capital divided into shares.(Albanian Company Law. Art.5) The founders of these companies can be natural or judicial persons, this means that other trade companies can be partners in a joint stock company. In general, a company is considered private company if it is out of the definition of a public company. According to ACL, private joint stock companies must have a capital higher than 2 million ALL(Albanian Lek) and public joint stock companies must have a capital higher than 10 million ALL.(ACL, art.107)

ACL offers two different set of rules for the organisation of a JSC: one-tier and two-tier structure. Speaking generally, the one-tier or unitary board system ( Berle A. \& Means G.C, (1993), The Modern Corporation and Private Property, (Legal Classics Library) is characterized by a single board that governs the company, and includes both executive and non-executive members. In such a setting, the supervisory body is often called the Board of Administrators. This governance structure can facilitate strong leadership structures and efficient decision-making. Nonexecutive and independent directors, however, play a crucial role in monitoring managers and reducing agency costs. This system is typical for companies based in countries with a common law tradition, for example the U.S and U.K.

On the other hand, the two-tiered or dual system, is characterized by the existence of distinct supervisory and management bodies. The former is commonly referred to as Supervisory Board and the latter as the Executive Board. Under this system, the day-to-day management of the company is handed down to the Executive Board, which is then controlled by the Supervisory Board (which in turn is elected by the General Meeting of Shareholders). These two bodies have distinct authorities and their composition cannot be mixed, e.g. members of the Executive Board cannot sit on the Supervisory Board and vice-versa. The advantage of the two-tiered system is a clear oversight mechanism, but it has been criticized for inefficient decision-making. This system is most famously represented in Germany.

Besides the one-tier system and the two-tiered system, many countries recognize a third governance structure, the hybrid system (International Finance Cooperation, 2010), which is essentially an amalgam of the two abovementioned models. According to this system, every joint- stock company must establish a Supervisory Board and a Board of Directors, with a possibility of organizing an Executive Board as well. Despite this, it cannot be found in Albanian Company Law any trace of this hybrid system. in mind:

Regardless of which system a country allows, the following (International Finance Cooperation, 2010) must be kept 
1- Firstly, there is always a trade-off between efficiency and control. When the agency problem or conflict of interest is high, shareholders may choose the two-tier system, but must realize that a tight monitoring governance system could tie managers' hands and render business operations and decision-making inefficient. On the other hand, in the case shareholders and managers trust each other, there is better efficiency to explore more business opportunities, and the company may choose a more pro-management oriented, one-tier board system.

2- While all systems have many elements in common, important differences do exist and these will affect the board's authority, structure and operations, and consequently the duties and obligations of directors. (These differences are embedded in, among other things, national legislation (legal tradition) organizational theory (composition requirements and functional distribution of authorities) corporate culture and will affect the supervisory body's authority, structure and operations).

\subsection{The one-tier model according to the $\mathrm{ACL}$}

The one-tier model in a JSC organization it is defined in Art 154 et seq of Albanian Company Law. According to this system, the Board of Administration is the central administrative organ. Board of Administration, is a combination of the supervisory and managing functions. This Board is composed by executive and non-executive members. This system in $\mathrm{ACL}$ has been modeled according to English Company Law.

According to Art. 115 of Albanian Company Law, in the Board of Administrators should be at least three or a greater number of members, but not more than 21 members. Members are individuals, most of whom must be independent and different from the administrators of the company. Members of the Board of Administrators are elected by the General Meeting with the majority required in paragraph 2 of Article 145 of this law (Albanian Company Law), by applying a term defined in the statute, which may not be longer than 3 years. Members of the Board of Administrators may be reelected.

The statute may provide that shareholders who hold together a number of shares representing at least 5 percent or a lower value of registered capital, have the right to appoint a member of the Board of Administrators with a special decision. Members so elected may not increase the number of members of the Board of Administrators on the maximum number of 21 members. Independent members of the Board of Administrators have to evaluate the persons who do not have a conflict of interest, as defined in paragraph 3 of Article 13 of this Law.

There are some restrictions about the election of the members of Board of Administrators. Members of the Board of Administrators may be elected by the shareholders and employees of the company, as well as from the ranks of other individuals outside the company. But a person cannot be elected as a member of the Board of Administrators, if at the same time, is:

a) a member of the Board of Administrators or Supervisory Board on two other companies registered in the Republic of Albania;

b) is the administrator of a parent company or a subsidiary of the company;

c) is the manager of another company, which has as an administrator or a member of the Board of Administrators a member of the Board of Administrators or the Supervisory Board of the first company. (Albanian Company Law, art.156)

Any appointment made in violation of section 2 of this article (art.156), is unlawful. Rights of third parties are protected under Article 12 of this Law.

Individuals who run to be appointed as members of the Board of Administrators shall immediately inform the company of any conflict of interest on membership on the boards of other companies. The General Meeting may at any time dismiss the members of Board of Administrators by simple majority.(Albanian Company Law, art.157.para.1)

According to Art. 154 of $\mathrm{ACL}$, the Board of Administration has the following rights and responsibilities (divided in managing and supervisory functions):

a) provide guidelines for administrators to implement policies of the company (this provision envisages the participation of the Board in the process of decision-making, but the business policies itself are set by the General Meeting (Albanian Company Law, art.135, para 2 (a)

b) control and monitor the implementation of trade policies by administrators;

c) taking measures at the request of the General Assembly, recommend the necessary decisions to be taken by General Assembly, and to implement the decisions of this latter;

d) convene the general meeting, whenever deemed necessary in the interests of company;

e) ensure that the company respect the law and accounting standards; 
f) review and check books, documents and assets of the company;

g) ensure that the annual financial statements, performance reports of the event, as well as other published reporting obligations required by law or statute, are accurately performed by the administrators. These documents must be approved and signed by all the members of Board of Administrators to be submitted to the General Assembly, together with a report of the Board of Administrators for approval and a description of management oversight during the financial year;

h) ensure that the audit of the books and accounting records carried out at least once a year by a certified public accountant, independent of the audit report to the General Assembly, to be made available to all members of the council administrators. Report of the Board of Administrators, referred to in the letter "e" of this section, must include an opinion on the report of the audit;

i) appoint and dismiss managers, share the power between them;

j) determine the remuneration of administrators;

k) approve taking on liabilities with a higher value than 5 percent of the assets of the company, resulting in the latest financial statements, certified, through the signing of loans or the issuance of bonds or other debt instruments (it is important to note, however, that this restriction is only a rule of internal management and does not limit the administrator's power to represent the company);

1) establish the creation of long-term trade cooperation and policy proposals for the establishment of new companies or groups (this express the function of the Board of Administrators as advisors to the administrators);

m) perform other actions specified in the law and statute.

2. In the cases provided for in paragraphs 3, 4 and 5 of Article 136 of this law, the board shall promptly convene a general meeting to consider whether the company should be wound up or to take other measures necessary and appropriate.

There is a rule when the consent of Board of Administrators is required for the transactions (Albanian Company Law, Art.207, this is true for any acquisition of more than $30 \%$ voting rights of another company).

- Acquisition of a controlling share in another company,

- The exercise of a decisive influence on another company,

- The participation on the formation of a new company, even if the subscription of capital does not lead to a controlling stake in this company.

It is important to stress that the main function of the Board of Administrators is the supervision of the administrator's conduct in running the company's business. This is stated in the previous provision, in subparagraph $1(\mathrm{~b})$ to $(\mathrm{g})$ and (i). The Board of Administrators has to supervise and monitor the implementation of the company's business policies by the administrators. So, it falls within the duty of Board of Administrators to appoint and dismiss the administrators and to propose the benefit-schemes for them. (The administrators remuneration has to be approved by the General Meeting, Art.160 (1) ACL)

The supervisory duties of Board of Administrators also include the ensuring of the company's compliance with the applicable laws and accounting standards. Regarding this the Board has to examine the company's books that are the accounting books and to approve the annual statement of accounts and report regarding the performance before presenting them to the general meeting. On the other hand the Board has to ensure that the annual audit of the company's books it is done by an independent and professional auditor. All these were previously mentioned in the article. Also it convenes the General Meeting at any time it is in the interest of the company. Other responsibilities of the Board of Administrators can be ruled by the Statute.

The main rules over the decision-making process of the Board of Administrators are defined in the Statute but also can be defined in the by-laws regulating its internal organization. The establishment of these by-laws and their amendments require a unanimous vote by the Board of Administrators (Albanian Company Law, art.161). The decisions of the Board are effective if more than the half of members are present in the voting procedure and are made by a simple majority of the present members (but the Statute can adapt new rules about the decision-making process). The chairman and vice-chairman have to be elected by the Board (Albanian Company Law, art.161 para 2) and they must not be administrators at the same time, but also it is not necessary that this person be an independent member of the Board of Administrators (he holds a casting vote in case of a tie).

\subsubsection{Administrators in one-tier system.}

According to Art. 158 of Albanian Company Law, the administrators are appointed by the Board of Administrators, as it is 
ruled in paragraph 1 of this article:

"The Board of Administrators shall appoint one or more natural persons as administrators of company, for a defined term in the statute, which cannot be longer than 3 years."

On the other hand the administrators of the company may be re-elected. Members of the Board of Administrators may perform the duties of the administrator as long as the majority of the members of the Board of Administrators are independent members, who do not perform this task. (Albanian Company Law, art.158) The appointment produces effects upon registration in the National Registration Centre and the rights of third parties are protected under Article 12 of this Law. The Statute of the company may establish special rules for the appointment of administrators.

The administrator of a parent company cannot be appointed as administrator of a subsidiary and vice versa. The administrator of a parent company cannot be the chairman of the Board of Administrators of a subsidiary and administrator of a subsidiary cannot be the chairman of the Board of Administrators of the parent company.(Article 158) Any appointment made in contravention of these provisions is null and void. Third parties' rights are protected under Article 12 of this Law. The Board of Administrators may dismiss the administrators at any time, and this right is not limited to the case in which the administrator has breached his duties or made something else that can be a legal reason for dismissing. It is necessary that administrators act in good faith and in the best interest of the company, in the process of decision-making.

The administrator in a Joint-stock company has the right to represent the company and to manage its business; this includes the acts and decisions that need to be made in managing the company. ( Bachner T., Schuster E-PH. \& Winner W., op.cit, 119) Nevertheless, we must say that the Board of Administrators and the administrator has divided functions, and the Statute must not confer rights and duties on the administrators which the law confers to the Board of Administrators.( Bachner T., Schuster E-PH and Winner W., op.cit, 120)

According to EU member states law, ( Ghezzi F. \& Malberti C., 'The two-tier model and the one-tier model of the corporate governance in the Italian reform of corporate law' (Research paper $\mathrm{nr} 15$ ) in the one-tier model of corporate governance, the board of directors is appointed by the shareholder's meeting. The board of directors manages the company. There is also an external (it can be called independent) auditor that controls the compliance with the accounting procedures. The final decision for the composition of the management bodies or their control is made by the shareholder's meeting. This mean that the most important characteristic of this model is that shareholder's meeting may remove the members of the board of directors at any time, being these latter dependent from this management body.

Regarding to the differences in terms between Albanian Law and EU member states law, it is necessary to underline that this difference isn't about administrators functions but for the definition used and how they are called. To make it more clear, if we have to make a study on both the terms "director" and "administrator", it is necessary to say that both terms represent the same function, as regarding to corporate governance. This is a result of the legal culture of western countries and of course as a result of the fact that Albanian Company Law is borrowed by the best practices of company law at one hand, but at the other it was necessary to have its originality.

\section{Harmonisation to EU Law}

Since the beginning of EU Company Law, there have been many directives being transposed in the national law of Member States. But there have been even some other states, not member states, such as Albania, that during the long way toward integration have decided to harmonise their national law with that of EU law. The legal status and registration of a company has been issues dealt with in all these states and even in the new Albanian Company Law. These rules can be found in the First Directive 68/151/EEC (OJ L 65 [14.03.1968] item 1, cf IV.2) that was complemented by Eleventh Directive 89/666/EEC (OJ L 395 [30.12.1989] 36-39) concerning disclosure requirements in respect of branches opened in a Member State by a company governed by the law of another state.

Other directives harmonizing the company law all over Member States were the Second Council Directive 77/91/EEC contains additional disclosure requirements for public limited liability companies on increasing and maintenance of subscribed capital, and the Twelfth Directive 89/667/EEC which requires to make possible the formation of a private limited liability company with only a single member, to all Member States. More or less these directives or parts of them are transposed in new Albanian Company Law trying to harmonize with EU law.

According to Article 70(3) of the Stabilisation-Association Agreement, there are some newly legal acts that are part of the legal reform toward the approximation of the legislation with the Acquis Communautaire in the area of company law. These acts are as follows: 
- Company Law ( Law no.9901 dated 14.04.2008 (Albanian Company Law) as amended)

- Public takeover Law (Law no.10236 dated 18.02.2010 (On takeover of companies with public offer)

- Securities Law (Law no.9879 dated 21.02.2008 (On securities)

- Registration and Disclosures Law (Law no.9723 dated 03.05.2007 (On the National Registration Center)

- Banking Law (Law no.9662 dated 18.12.2006 (On Banks in the Republic of Albania) amended in December 2011)

- Accounting and Financial Statements Law (Law no.9228 dated 29.04.2004 (On Accounting and Financial Statements) as amended)

- Certified Accountants Law (Law no.10091dated 05.03.2009 (On Legal Audit and the Organization of Certified Financial Accountants Profession) as amended)

Regarding our matter of issue, on corporate governance the European Union policies were not interfering with the national laws of Member States until the directives of 2004 and 2007 (as we previously have mentioned) were approved. Nevertheless these directives didn't have an importance on the new Albanian Company Law, since in Albania there are not listed-companies. On the other hand this latter Law stipulates the optional membership of employee representatives upon agreement between employees and the company management.(Albanian Company Law, art.21) Regarding European standards this new Law foresees a legal obligation for company representatives to inform the Employee Council, and the right of the latter to be informed directly on activities, decisions, policies and strategies that affect employee interests or issue opinions and recommendations and get feedback on their addressing.(Albanian Company Law, art.20)

\section{Conclusion}

1- The freedom of establishment, as one of four freedoms of Community Law, has become part of original Treaty of Rome which created European Economic Community in 1957, and now has become Article 49 of Treaty on Functioning of European Union. The importance of this in European Union legislation is that prohibits restrictions regarding the freedom of establishment of any national of Member State in the territory of another Member State.

In accordance with this there have been implemented many Directives in European Union Member States during these years. However, Albania is not part of European Union, as such the ECJ decisions are followed by the courts or used in the judge's reasoning of the decisions, but they do not have direct effect on the companies. On the other hand, in the Stabilization and Association Agreement there is an article that imposes restrictions on discrimination of EU businesses.

2- Albania has decided to harmonize the national law with that of European law, but this has been difficult, in that Albanian legislator mostly has deviated in their provisions, intentionally or not, from European Union Law. Why did happen this? One could realize that this came from the incapability of Albanian market to absorb European Union provisions, or from the incapability of Albanian politicians walk in the right path of European Union because of the fact this could jeopardize their economic interests. As a result Albanian legislator deviated in harmonizing the law with that of EU law, because he wanted to protect his interests (economic interests) since mostly Albanian legislators are part of economic environment. By harmonizing and ruling the company law according to EU law, it could have been impossible for these legislator-businesspersons to act and make business up to their rules and raise their profits. Also, many lawyers have achieved best positions only by nepotism or doing some illegal services to politicians who awarded them. This made that there are not qualified corporate lawyers, and even if there are some new generation lawyers, educated in western countries, there is no place for them because of the fact they are not promoted or supported by the old generation. As a result it is urgently needed the expertise of qualified lawyers, not only to understand better the new trends on corporate law but to implement the law properly.

It cannot be said that the private sector and representatives of the companies, have become aware of the importance of corporate governance. The shareholders interest on comprehensive corporate governance principles and practices is still low. That is result of the lack of needed corporate governance cultures among their boards and management, but also of the presence of the informal sector, non registered businesses that have consequences in terms of tax evasion, labor market distortions and unfair competition.

There is no adequate efficiency and capacities of judicial system dealing with corporate governance matters, associated with limitations on the level of implementing the decisions and rule of law in general.

The Albanian legislation on company law is, overall, consistent with the Acquis on disclosure requirements, 
takeover bids, formation of public limited liability companies and alteration of their capital and rights of shareholders in listed companies.( Stabilisation and Association Report for Albania of the European Commission (2010) Preparations for bringing Albanian legislation into line with the Acquis as regards reporting and documentation requirements in the case of mergers and divisions are on track. According to the last European Commission Stabilisation and Association Report for Albania, some progress was made in the areas of corporate accounting and auditing, but legislation remains to be aligned with the acquis and the Public Oversight Body needs to be strengthened.

\section{References}

Alfred F. Conard, Corporations in Perspective (Foundation Press, New York, 1976).

Harvey H. Segal, Corporate Makeover: The Reshaping of the American Economy (Viking, New York, 1989).

Robert A.G. Monks and Nell Minow, Corporate Governance (third edition), Blackwell publishing, 2003.

Carmen Todica, Alexandru Todica," If the administrator of the trading company can be employed under the legislative framework provided by the Company law, the Labor Code and the Civil Code", Law working paper, "Titu Maiorescu" University, Faculty of Law Bucharest.

Joseph A. Grundfest, "Just Vote No: A Minimalist Strategy for Dealing with Barbarians Inside the Gates," 45 Stanford Law Review, 4, Apr. 1993.

Ghezzi Federico and Malberti Corrado, "Corporate Law Reforms in Europe: The Two-Tier Model and the One-Tier Model of Corporate Governance in the Italian Reform of Corporate Law" (January 19, 2007), Bocconi Legal Studies Research Paper No. 15.

Guido Ferrarini, "Corporate Governance changes in the 20-th Century, a view from Italy", Law paper no 29/2005, ECGI Working Paper Series in Law.

Bachner Thomas, Schuster Edmund-Philipp and Winner Martin, The new Albanian company law: interpreted according to its sources in European law. Center of Legal Competence, Tirana 2009, Albania.

Revoltella Debora, Haiss Peter \& Fink Gerhard, "Corporate Governance in Central and Eastern Europe: Transition management is a tough job. "Two Law Papers, Amsterdam, 1998 SUERF Studies.

OECD Principles of Corporate Governance, 2004.

International Finance Corporation-Corporate Governance Manual (second edition) IFC2010.

Comparative Study of Corporate Governance Codes Relevant to the European Union and Its Member States, On behalf of European Commission, Internal Market Directorate General (final report with annexes) January 2002.

John P. Davis, Corporations: A study of the origin and development of great business combinations and of their relation to the authority of the state (Capricorn, New York 1961).

Gregory, H.J., The Globalisation of Corporate Governance," Global Counsel, Parts 1 \& 2 (September \& October 2000).

Grossman, S. and O. Hart, "One-Share-One-Vote and the Market for Corporate Control" Journal of Financial Economics, 20:175-202 (1988).

International Corporate Governance Network, Global Share Voting Principles (July, 1998) www.icgn.org.

Nestor, S., "Corporate Governance Trends and Developments in the OECD Area: Where Do We Go From Here?," International Financial Law Review (2001).

OECD Steering Group on Corporate Governance, Company Law in OECD Countries - A Comparative Overview(draft, forthcoming 2002) ("OECD Comparative Law Overview").

Millstein, I. M., "The Evolution of Corporate Governance in the United States - Briefly Told," Paper presented at the EU Rome Forum sponsored by The Mentor Group (Rome, Italy 13-15 September 2001).

Millstein, I. M., "Corporate Governance: The Role of Market Forces," OECD Observer, No.221/222 (Summer 2000).

Alfred F. Conard, Corporations in Perspective (Foundation Press , New York, 1976).

Commission Recommendation of 15 February 2005 on the role of non-executive or supervisory directors of listed companies and on the committees of the supervisory board (paragraph 4) Official Journal of European Union, 25.02.2005.

Eisenberg Melvin Aron, "The structure of Corporation Law" Columbia Law Review, 7 November 1989.

John J.Clancy, The invisible Powers, The language of Business (Lexington Books, Lexington, MA, 1989).

S. Beligrădeanu-Derogations from the common labour law included in the Law no. 31/1990 regarding trading companies, in the Law no. 912/1990.

C. Roşu-Natura juridică a raporturilor şi societatea comercială [Legal Nature of the Relationships and the Trading Company] in RRD no. $4 / 2004$.

Adolf A. Berle and Gardiner C. Means, The Modern Corporation and Private Property (Legal Classics Library, 1993).

Commission Recommendation (SEC 2009 (580); SEC 2009 (581).

Commission Recommendation complementing Recommendations 2004/913/EC and 2005/162/EC as regards the regime for the remuneration of directors of listed companies $\{\mathrm{SEC}(2009) 580\}$ \{SEC(2009) 581\}.

Council Directive 2001/23/EC of 12 March 2001 of the approximation of the laws of the Member States relating to the safeguarding of employees' rights in the event of transfers of undertakings, businesses or parts of undertakings of businesses. (OJ L 82, 22.03.2001).

Albanian Company Law(Law no 9901, date 14.04.2008 "On entrepreneurs and companies"-(alb) Per tregtaret dhe shogerite tregtare) (changed by Law no 10476, dating 27.10.2012).

R.W. Hamilton, "Corporate Governance in America 1950-2000; Major changes but uncertain benefits", Journal of Corporation Law 25, No 2 (1999-2000).

Malltezi Argita, "Albanian Company Law", Mediaprint 2011. 